\title{
A COMPREHENSIVE STUDY OF SALIVARY GLAND TUMOURS IN A TERTIARY CARE CENTRE OF CENTRAL INDIA
}

\author{
Rajiv Jain ${ }^{1}$, Abhishek Kansal2
}

1 Professor, Department of Surgery, Sri Aurobindo Medical College and PG Institute, Indore, Madhya Pradesh. ${ }_{2}^{2}$ Assistant Professor, Department of Surgery, Sri Aurobindo Medical College and PG Institute, Indore, Madhya Pradesh.

ABSTRACT
BACKGROUND
Salivary gland tumours are very common in India. The present study has analysed the incidence, clinical profile and differential
diagnosis of various salivary gland tumours.
The aims of this study are to know the incidence of various salivary gland tumours in different age groups and in both sexes to
know the distribution of different benign and malignant tumours in each variety of salivary glands.

\section{MATERIALS AND METHODS}

This study was conducted in a prospective and retrospective ways covering the patients admitted with salivary gland tumours in a period of 6 years from 2000 to 2006. Total 59 patients were enrolled and their data was recorded.

\section{RESULTS}

Salivary gland tumours are most common in $4^{\text {th }}$ and $5^{\text {th }}$ decade of life. The incidence of salivary gland tumours is almost equal in both sexes with slight female preponderance. The salivary gland most commonly found involved is the parotid. Benign neoplasms are the most common swellings of salivary glands. The most common benign tumour of salivary gland is pleomorphic adenoma. The most common location of pleomorphic adenoma is the parotid gland. The most common malignant tumour of salivary glands is mucoepidermoid carcinoma.

\section{CONCLUSION}

The present study gives some important data about salivary gland tumours and emphasises the need for a more bigger study involving a larger number of patients.

\section{KEYWORDS}

Salivary Gland Tumours, Parotid, Submandibular, Pleomorphic Adenoma.

HOW TO CITE THIS ARTICLE: Jain R, Kansal A. A comprehensive study of salivary gland tumours in a tertiary care centre of Central India. J. Evolution Med. Dent. Sci. 2017;6(15):1200-1203, DOI: 10.14260/Jemds/2017/261

\section{BACKGROUND}

It is astonishing to consider how little is known of the pathological processes that affect any organ that is so near the surface, so accessible for clinical examination, so easy biopsies, so simple to obtain secretions for analysis and that organ is salivary gland.

Controversies surrounding the diagnosis and management of salivary gland masses often involve the limits of our technology. The primary controversy often lies not in how to treat a given disease, but by what means the diagnosis can be established without doubt. The present study is a modest attempt to find out the reasonable solutions of existing controversies.

The major salivary glands include parotid glands, submandibular glands and sublingual glands. There are also approximately 750 minor salivary glands scattered throughout the submucosa of the oral cavity, oropharynx, hypopharynx, larynx, parapharyngeal space and nasopharynx.

Financial or Other, Competing Interest: None.

Submission 08-01-2017, Peer Review 04-02-2017,

Acceptance 10-02-2017, Published 20-02-2017.

Corresponding Author:

Dr. Rajiv Jain,

\#27, Anand Bagichi, Agrawal Nagar,

Indore-452001, Madhya Pradesh.

E-mail: drrajivjain16@yahoo.com

DOI: $10.14260 /$ jemds $/ 2017 / 261$
Salivary gland neoplasms are relatively uncommon constituting 3 to $4 \%$ of all head and neck neoplasms. The incidence of salivary gland tumours is 1 to 2 cases per 100,000 people. Majority of them arise in parotid gland (70\%), whereas tumours of submandibular glands $(22 \%)$ and sublingual and minor salivary glands (8\%) are less common. Salivary gland neoplasms most often present as slow growing, well-circumscribed masses. Symptoms such as pain, rapid growth, nerve weakness and paraesthesias and signs of cervical lymphadenopathy and fixation to skin or underlying muscles suggest malignancy.

Present study is to know the occurrence and incidence of various types of salivary gland tumours in patients presenting to M. Y. Hospital. The clinical presentation of these tumours is analysed. The differential diagnosis of these tumours is discussed. The histopathological examination reports of all cases are followed and the results analysed.

\section{MATERIALS AND METHODS}

M. Y. Hospital is a big tertiary care hospital covering a wide area with large number of admission of patients of various surgical disorders. The study was carried out in the Department of Surgery, M. G. M Medical College and M. Y Hospital, Indore.

\section{Time Period}

The total duration of the study was 6 years, 3 years retrospective and 3 years prospective. 
A. Retrospective study - Including the patients admitted between the years from 2000 to 2003 .

B. Prospective study - Including the patients admitted between the years from 2004 to 2006 .

For prospective study, the patients of salivary gland tumours admitted in the Department of Surgery were included. For retrospective study, 3-year data of patients of salivary gland tumours was reviewed.

\section{Inclusion Criteria}

1. Patients with swelling in parotid, submandibular, sublingual and minor salivary glands.

2. Those patients who were willing to take part in the study.

3. Patients who have taken complete treatment in the hospital.

\section{Exclusion Criteria}

1. The patients who were not willing to take part in the study.

2. The patients who have not taken complete treatment due to financial/social constraints.

3. The pregnant females.

4. The patients with immunodeficiency diseases.

\section{Protocol for Workup}

1. Clinical symptoms and signs.

2. Lab investigations like $\mathrm{Hb}, \mathrm{T}$ and $\mathrm{D}$, Serum Urea, Creatinine, RBS.

3. F. N. A. Cytology/Biopsy of the salivary gland swelling.

4. Imaging studies - X-ray, USG, CT-Scan, Sialography, MRI etc. as per the need.

5. Treatment Modalities.

6. Histopathological Examination report.

\section{Retrospective Study}

In this study, case records of the patient admitted in the surgery wards from 2000 to 2003 were studied and their details were carefully recorded.

\section{Prospective Study}

In this part of the study, patients of salivary gland tumours admitted in Surgery Wards from 2004 to 2006 were examined clinically, investigated, followed during operative procedure and followed till their discharge and at followup visits.

\section{RESULTS}

This present study on salivary gland tumours was carried out in the admitted patients of M. Y. Hospital, Indore.

Total no. of cases was 59 (n). Total no. of cases in the retrospective study were 30 and the total no. of cases in the prospective study were 29 . The following observations were made.

\begin{tabular}{|c|c|c|}
\hline Sex & Male & Female \\
\hline Retrospective Study & 17 & 13 \\
\hline Prospective Study & 12 & 17 \\
\hline Total & $29(49.15 \%)$ & $30(50.85 \%)$ \\
\hline
\end{tabular}

\begin{tabular}{|c|c|c|c|}
\hline $\begin{array}{c}\text { Age } \\
\text { Groups }\end{array}$ & $\begin{array}{c}\text { Retrospective } \\
\text { Study }\end{array}$ & $\begin{array}{c}\text { Prospective } \\
\text { Study }\end{array}$ & Total \\
\hline $00-15$ & 2 & 4 & $6(10.17 \%)$ \\
\hline $16-30$ & 3 & 6 & $9(15.25 \%)$ \\
\hline $31-45$ & 13 & 12 & $25(42.37 \%)$ \\
\hline $46-60$ & 7 & 3 & $10(16.25 \%)$ \\
\hline $61-75$ & 5 & 2 & $7(11.86 \%)$ \\
\hline$>75$ & - & 2 & $2(3.39 \%)$ \\
\hline Total & $\mathbf{3 0}$ & $\mathbf{2 9}$ & $\mathbf{5 9}$ \\
\hline \multicolumn{2}{|r|}{}
\end{tabular}

Table 2. Table showing Age Distribution of Cases

\begin{tabular}{|c|c|c|c|}
\hline $\begin{array}{c}\text { Salivary } \\
\text { Gland }\end{array}$ & $\begin{array}{c}\text { Retrospective } \\
\text { Study }\end{array}$ & $\begin{array}{c}\text { Prospective } \\
\text { Study }\end{array}$ & Total \\
\hline Parotid & 20 & 20 & $40(67.79 \%)$ \\
\hline Submandibular & 8 & 8 & $16(27.12 \%)$ \\
\hline Sublingual & - & 1 & $1(1.69 \%)$ \\
\hline $\begin{array}{c}\text { Minor Salivary } \\
\text { Glands }\end{array}$ & 2 & - & $2(3.39 \%)$ \\
\hline Total & $\mathbf{3 0}$ & $\mathbf{2 9}$ & $\mathbf{5 9}$ \\
\hline \multicolumn{4}{|r|}{$\begin{array}{r}\text { Table Table showing the Distribution } \\
\text { of Salivary Gland Involved }\end{array}$} \\
\hline
\end{tabular}

\begin{tabular}{|c|c|c|}
\hline & Benign Neoplasm & Malignant Neoplasm \\
\hline Retrospective & 24 & 6 \\
\hline Prospective & 21 & 8 \\
\hline Total & $\mathbf{4 5}(\mathbf{7 6 . 2 7 \% )}$ & $\mathbf{1 4}(\mathbf{2 3 . 7 2 \% )}$ \\
\hline \multicolumn{2}{|c|}{ Table 4. Table showing the Diagnosis of Cases } \\
\hline
\end{tabular}

\begin{tabular}{|c|c|c|c|c|c|}
\hline $\begin{array}{c}\text { Pathological } \\
\text { Variety }\end{array}$ & $\begin{array}{c}\text { Parotid } \\
\text { Gland }\end{array}$ & $\begin{array}{c}\text { Sub- } \\
\text { mandibular } \\
\text { Gland }\end{array}$ & $\begin{array}{c}\text { Sublingual } \\
\text { Gland }\end{array}$ & $\begin{array}{c}\text { Minor } \\
\text { Salivary } \\
\text { Glands }\end{array}$ & Total \\
\hline $\begin{array}{c}\text { Pleomorphic } \\
\text { Adenoma }\end{array}$ & $\begin{array}{c}28 \\
{[71.79 \%]}\end{array}$ & $\begin{array}{c}10 \\
{[25.64 \%]}\end{array}$ & 0 & $\begin{array}{c}1 \\
{[2.56 \%]}\end{array}$ & 39 \\
\hline $\begin{array}{c}\text { Warthin's } \\
\text { Tumour }\end{array}$ & $\begin{array}{c}4 \\
{[100 \%]}\end{array}$ & $\begin{array}{c}0 \\
{[0.00 \%]}\end{array}$ & 0 & $\begin{array}{c}0 \\
{[0.00 \%]}\end{array}$ & 4 \\
\hline $\begin{array}{c}\text { Basal Cell } \\
\text { Adenoma }\end{array}$ & $\begin{array}{c}1 \\
{[100 \%]}\end{array}$ & $\begin{array}{c}0 \\
{[0.00 \%]}\end{array}$ & 0 & $\begin{array}{c}0 \\
{[0.00 \%]}\end{array}$ & 1 \\
\hline $\begin{array}{c}\text { Myo- } \\
\text { epithelioma }\end{array}$ & $\begin{array}{c}1 \\
{[100 \%]}\end{array}$ & $\begin{array}{c}0 \\
{[0.00 \%]}\end{array}$ & 0 & 0 & 1 \\
\hline Total & $\mathbf{3 4}$ & $\mathbf{1 0}$ & $\mathbf{0}$ & $\mathbf{1}$ & $\mathbf{4 5}$ \\
\hline
\end{tabular}

Table 5. Table showing the Location of 45 Benign Salivary Gland Tumours [Retrospective and Prospective]

\begin{tabular}{|c|c|c|c|c|c|}
\hline $\begin{array}{l}\text { Pathological } \\
\text { Variety }\end{array}$ & $\begin{array}{l}\text { Parotid } \\
\text { Gland }\end{array}$ & $\begin{array}{c}\text { Sub- } \\
\text { mandibular } \\
\text { Gland } \\
\end{array}$ & $\begin{array}{c}\text { Sub- } \\
\text { lingual } \\
\text { Gland } \\
\end{array}$ & \begin{tabular}{|c|} 
Minor \\
Salivary \\
Glands \\
\end{tabular} & Total \\
\hline $\begin{array}{c}\text { Muco- } \\
\text { epidermoid } \\
\text { Carcinoma }\end{array}$ & $\begin{array}{c}5 \\
{[83.33 \%]}\end{array}$ & $\begin{array}{c}1 \\
{[16.66 \%]}\end{array}$ & 0 & 0 & 6 \\
\hline $\begin{array}{c}\text { Adenoid Cystic } \\
\text { Carcinoma }\end{array}$ & 0 & $\begin{array}{c}2 \\
{[100.00 \%]}\end{array}$ & 0 & 0 & 2 \\
\hline $\begin{array}{c}\text { Carcinoma Ex- } \\
\text { Pleomorphic } \\
\text { Adenoma }\end{array}$ & $\begin{array}{c}1 \\
{[33.33 \%]}\end{array}$ & [33.33\%] & 0 & $\begin{array}{c}1 \\
{[33.33 \%]}\end{array}$ & 3 \\
\hline $\begin{array}{l}\text { Acinic Cell } \\
\text { Carcinoma }\end{array}$ & 0 & $\begin{array}{c}1 \\
{[50.00 \%]}\end{array}$ & $\begin{array}{c}1 \\
{[50 \%]}\end{array}$ & $\begin{array}{c}0 \\
{[0.00 \%]} \\
\end{array}$ & 2 \\
\hline $\begin{array}{c}\text { Adeno- } \\
\text { carcinoma NOS }\end{array}$ & 0 & $\begin{array}{c}1 \\
{[100 \%]}\end{array}$ & 0 & 0 & 1 \\
\hline $\begin{array}{c}\text { Epithelial- } \\
\text { Myoepithelial } \\
\text { Carcinoma }\end{array}$ & 0 & 0 & 0 & 0 & 0 \\
\hline $\begin{array}{c}\text { Papillary } \\
\text { Cysta- } \\
\text { denocarcinoma }\end{array}$ & 0 & 0 & 0 & 0 & 0 \\
\hline Total & 6 & 6 & 1 & 1 & 14 \\
\hline
\end{tabular}

Table 6. Table showing the Location of 14 Malignant Salivary Gland Tumours [Retrospective and Prospective] 


\section{DISCUSSION}

The retrospective study was done from the year 2001 to 2003 and the prospective study was done from 2004 to 2006 . In the retrospective group 30 cases were included and in the prospective group 29 cases were included. Thus, total 59 cases were studied.

In the retrospective group males predominated with $56.6 \%$ of the total cases, whereas females were $43.3 \%$. In the prospective group females predominated with $58 \%$ of the total cases, whereas males were $42 \%$. However, in the comprehensive study, the sex ratio was found to be almost equal with female comprising $51 \%$ and male $49 \%$. Thus, the sex ratio was 0.96 with slight female preponderance. In a similar study done by Pablo Augustin et al, they have found a higher prevalence of salivary gland tumours in females [60\%]. ${ }^{1}$ In contrast, Frade Gonzalez et $\mathrm{al}^{2}$ observed a predominance of salivary gland tumours in the male group (58.75\%).

The incidence of salivary gland neoplasms was most common in the $4^{\text {th }}$ and $5^{\text {th }}$ decade with $42.4 \%$ of cases belonging to age group 31 - 45 years, which is similar to the finding observed by Pablo Augustin et al, ${ }^{1}$ while Frade Gonzalez et $\mathrm{al}^{2}$ found highest incidence in the $7^{\text {th }}$ decade of age.

Next high incidence was found in the age group $46-60$ years with $16.3 \%$ of cases. The incidence was least common in the age group $>75$ years with only 2 cases $(3.4 \%)$. The incidence in paediatric age group (00 - 15 years) was also less with only 6 cases $(10.2 \%)$.

In our study, the most common salivary gland involved was the parotid gland. It was involved in total 40 cases (67.8\%). The next common salivary gland in the frequency of involvement was submandibular gland, which was involved in $27.1 \%$ of cases. The sublingual and minor salivary gland involvement was very rare. They were involved only in $1.7 \%$ and $3.4 \%$ of cases respectively. Similar observation was made in a study conducted by Eveson JW et $\mathrm{al}^{3}$ and Pinkston JA et al. 4

In this study, the benign neoplasms of salivary gland were found to have higher incidence as compared to malignant neoplasm and non-neoplastic swellings; 28 cases i.e. $47.5 \%$ were benign neoplasms of salivary glands, whereas malignant neoplasms comprised $18.6 \%$ of cases. We found the similar findings in the histopathological analysis done at the Armed Forces Institute of Pathology. 5

The incidence of malignancy was found to increase in the extremes of the age groups, i.e. in the paediatric and the geriatric age groups. Out of the total 6 no. of cases in the paediatric age group, 2 were malignant (33\%). Out of the total 9 no. of cases in the age group > 60 years, 6 were malignant $(66 \%)$. Similar findings were observed in a study conducted by Narala Srivani et al. 6

Also, the incidence of malignancy was more in the sublingual and minor salivary glands as compared to parotid and submandibular salivary glands. Out of the 2 cases of minor salivary gland tumours, 1 was malignant (Incidence $50 \%$ ). Only 1 case of sublingual gland tumour was noticed in our study and it was malignant (Incidence 100\%). Out of the 40 cases of parotid tumours, 6 were malignant (15\%). Out of the 16 cases of submandibular tumours, 6 were malignant $(37.5 \%)$. The preponderance of malignant tumours in sublingual and minor salivary glands was also observed in the study conducted by Narala Srivani et al. ${ }^{6}$

The most common benign major and minor salivary gland tumour was the pleomorphic adenoma, which constituted $66 \%$ of the total cases studied ( 39 cases out of 59 studied). In our study, we found that the most common location of pleomorphic adenoma was the parotid gland (71.7\%) followed by the submandibular gland (25\%). We found 1 case of pleomorphic adenoma in minor salivary gland, but we did not find any case of pleomorphic adenoma in sublingual glands.

In our study, the most common malignant salivary gland tumour was Mucoepidermoid Carcinoma, which was found in 6 cases [42.85\%] out of total 14 cases of malignant tumours. Similar observation was made in the study conducted by Pinkston JA et al,4 who observed that Mucoepidermoid carcinoma was the most frequent malignant tumour (51.3\%). This observation is in contrast to the study conducted by Nagler et al, $^{7}$ in which they have found that the most commonly encountered malignant tumour was adenocarcinoma [including the acinic-cell and low-grade polymorphous subtypes] [27.7\%]. In the study conducted by Narala Srivani et al, ${ }^{6}$ they have found that the most common malignant tumour was adenoid cystic carcinoma followed by carcinoma, ex-pleomorphic adenoma and polymorphous lowgrade adenocarcinoma.

\section{CONCLUSION}

The main Results of our Study are -

1. Salivary gland neoplasms are relatively uncommon constituting 3 to $4 \%$ of all head and neck neoplasms. The incidence of salivary gland tumours is 1 to 2 cases per 100,000 people.

2. The incidence of salivary gland tumours is almost equal in both sexes with slight female preponderance.

3. Salivary gland tumours are most common in $4^{\text {th }}$ and $5^{\text {th }}$ decade of life. Incidence is rare in extremes of life, i.e. in the childhood and the old age.

4. The salivary gland most commonly found involved is the parotid followed by submandibular gland. Frequency in minor salivary gland is very less, while the sublingual gland tumours are rare.

5. Benign neoplasms are the most common swellings of salivary glands. Malignant neoplasms and non-neoplastic swellings are less frequently seen.

6. Incidence of malignant tumours is high in the paediatric and old age patients. Most of the neoplasms in the middle age group are benign.

7. Most of the parotid and submandibular gland tumours are benign, while the majority of sublingual and minor salivary gland tumours are malignant.

8. The most common benign tumour of salivary glands is pleomorphic adenoma. The most common location of pleomorphic adenoma is the parotid gland.

9. The most common malignant tumour of salivary glands is mucoepidermoid carcinoma.

10. In this study, we have done a modest attempt to solve some unresolved issues regarding salivary gland tumours. We believe that there is a need for further study on this subject. 


\section{REFERENCES}

[1] Vargas PA, Gehard R, Fiho AVJ, et al. Salivary gland tumors in a Brazilian population: a retrospective study of 124 cases. Rev Hosp Clin Fac Med Sao Paulo 2002;57(6):271-6.

[2] Gonzalez FC, Ramirez LA, Caballero GT, et al. Epidemiological study of salivary gland tumours. Rev Laryngol Otol Rhinol (Bord) 1999;120:331-6.

[3] Eveson JW, Cawson RA. Salivary gland tumors. A review of 2410 cases with particular reference to histological types, site, age and sex distribution. J Pathol 1985;146(1):51-8.
[4] Pinkston JA, Cole P. Incidence rates of salivary gland tumors: results from a population-based study. Otolaryngol Head Neck Surg 1999;120(6):834-40.

[5] Ellis GL, Auclair PL. Tumors of the salivary glands. In: Ellis GL, Auclair PL. eds. Armed Forces Institute of Pathology. $3^{\text {rd }}$ series, Fasc 17. Philadelphia: WB Saunders 1995;129-34.

[6] Srivani N, Srujana S, Shahista S, et al. Spectrum of salivary gland tumors - a five year study. IAIM 2016;3(7):132-6.

[7] Nagler RM, Laufer D. Tumors of the major and minor salivary glands: review of 25 years of experience. Anticancer Res 1997;17(1B):701-7. 